\title{
Limited replication of yellow fever 17DD and 17D-Dengue recombinant viruses in rhesus monkeys
}

\author{
GISELA F. TRINDADE ${ }^{1,2}$, RENATO S. MARCHEVSKY ${ }^{3}$, ANA M.B. DE FILLIPIS ${ }^{2}$, \\ RITA M.R. NOGUEIRA ${ }^{2}$, MYRNA C. BONALDO ${ }^{1}$, PEDRO C. ACERO $^{4}$, ELENA CARIDE ${ }^{3}$, \\ MARCOS S. FREIRE ${ }^{3}$ and RICARDO GALLER ${ }^{3}$ \\ ${ }^{1}$ Departamento de Bioquímica e Biologia Molecular, Fundação Oswaldo Cruz, Av. Brasil, 4.365, Manguinhos \\ 21045-900 Rio de Janeiro, RJ, Brasil \\ ${ }^{2}$ Departamento de Virologia, Fundação Oswaldo Cruz, Av. Brasil, 4.365, Manguinhos, 21045-900 Rio de Janeiro, RJ, Brasil \\ ${ }^{3}$ Instituto de Tecnologia em Imunobiológicos, Fundação Oswaldo Cruz, Av. Brasil, 4.365, Manguinhos \\ 21045-900 Rio de Janeiro, RJ, Brasil \\ ${ }^{4}$ Departamento de Genética, Fundação Oswaldo Cruz, Av. Brasil, 4.365, Manguinhos, 21045-900 Rio de Janeiro, Brasil
}

Manuscript received on August 20, 2007; accepted for publication on December 13, 2007; presented by ALEXANDER W.A. KELLNER

\begin{abstract}
For the development of safe live attenuated flavivirus vaccines one of the main properties to be established is viral replication. We have used real-time reverse transcriptase-polymerase chain reaction and virus titration by plaque assay to determine the replication of yellow fever 17DD virus (YFV 17DD) and recombinant yellow fever 17D viruses expressing envelope proteins of dengue virus serotypes 2 and 4 (17D-DENV-2 and 17D-DENV-4). Serum samples from rhesus monkeys inoculated with YFV 17DD and 17D-DENV chimeras by intracerebral or subcutaneous route were used to determine and compare the viremia induced by these viruses. Viral load quantification in samples from monkeys inoculated by either route with YFV 17DD virus suggested a restricted capability of the virus to replicate reaching not more than $2.0 \log _{10} \mathrm{PFU} \mathrm{mL}-1$ or $3.29 \log _{10}$ copies $\mathrm{mL}^{-1}$. Recombinant 17D-dengue viruses were shown by plaquing and real-time PCR to be as attenuated as YF 17DD virus with the highest mean peak titer of $1.97 \log _{10}$ PFU $\mathrm{mL}^{-1}$ or $3.53 \log _{10}$ copies $\mathrm{mL}^{-1}$. These data serve as a comparative basis for the characterization of other 17D-based live attenuated candidate vaccines against other diseases.
\end{abstract}

Key words: yellow fever, dengue, vaccine, attenuation, replication, real-time RT-PCR.

\section{INTRODUCTION}

Flaviviruses are positive-strand RNA viruses primarily transmitted by infected mosquitoes or ticks. They include major human pathogens, such as yellow fever, dengue, Japanese encephalitis, Tick-borne encephalitis and West Nile viruses (YFV, DENV, JEV, TBEV and WNV). Dengue viruses (DENV) has four distinct but closely related serotypes, DENV-1, DENV-2, DENV3 and DENV-4 that are distinguished by neutralization test (Russell and Nisalak 1967) and constitute a distinct

Correspondence to: Ricardo Galler

E-mail: rgaller@bio.fiocruz.br antigenic complex within the flaviviruses (Calisher et al. 1989). Dengue is a mosquito-borne flavivirus infection, which has become a major global public health concern due to a dramatic growth in its prevalence. Two and a half billion people are at risk of infection. Annually, over 50 million infections and 24,000 deaths are due to DENV (Gubler 2004). The only flavivirus vaccines available include yellow fever (YF), which is based on live attenuated YFV 17D (Monath 2003), Japanese encephalites (JE) and Tick-borne encephalitis (TBE), which are based on inactivated virus preparations. A live attenuated virus vaccine (SA-14-14-2) is also available for JE in China. 
No licensed dengue vaccine is available at this time, although there are some promising live attenuated vaccine candidates under development (Blaney et al. 2005, Durbin et al. 2001, Edelman et al. 2003, Guirakhoo et al. 2006, Kanesa-Thasan et al. 2001, Sun et al. 2003, 2006, Sabchareon et al. 2002, 2004).

The genome of all flaviviruses encodes a single long polyprotein processed to yield capsid (C), premembrane (prM), and envelope (E) structural proteins, followed by seven nonstructural proteins (NS1, NS2A, NS2B, NS3, NS4A, NS4B and NS5) synthesized, in that order, in virus infected cells (Lindenbach and Rice 2001). This knowledge led to infectious clone technology, which allows direct manipulation of the viral genome and has opened new possibilities for flavivirus vaccine development. One major approach has been the creation of chimeric flaviviruses, using the backbone of an attenuated virus in which certain genomic regions of interest have been replaced with the equivalent regions derived from another flavivirus against which a vaccine is needed (reviewed by Lai and Monath 2003).

Towards the development of vaccines to dengue, numerous efforts have been directed at establishing an animal model that reflects the disease patterns observed in humans (Bente and Rico-Hesse 2006) but all have their limitations. Several species of nonhuman primates have been infected with dengue viruses but none has shown clinical signs attributable to the viral infection. Notwithstanding, monkeys show some degree of viremia (up to $5 \log _{10} \mathrm{PFU} \mathrm{mL} \mathrm{m}^{-1}$ ) and a consistent neutralizing antibody response. High viremias have been correlated with severe dengue in man (Vaughn et al. 1997, 2000).

Several monkey species are highly susceptible to YFV with high viremia (up to $8 \log _{10} \mathrm{PFU} \mathrm{mL} \mathrm{m}^{-1}$ ) and fatal infection with clinical manifestations that resemble YF in man (Monath 2003). A major characteristic of the attenuated vaccine $17 \mathrm{D}$ virus is the loss of hepatotropism and reduced viremia after intracerebral, intrahepatic or subcutaneous inoculation $\left(<3 \log _{10} \mathrm{PFU} \mathrm{mL}^{-1}\right)$. Consequently one parameter for considering the safety of recombinant $17 \mathrm{D}$-dengue viruses is limited replication in nonhuman primates. Data from sub-cutaneous immunization of mice and monkeys with recombinant 17DDENV-2 and 17D-DENV-4 viruses (Galler et al. 2005, Galler R, Marchevsky RS and MS Freire, unpublished data) indicate that both elicited significant neutralizing antibody responses. These responses correlated with protection from challenge with wild type DENV-2 (Galler et al. 2005).

Here, we have compared viremia levels of YFV 17DD vaccine virus, by plaque assay and real-time reverse transcriptase-polymerase chain reaction (RT-PCR), after inoculation of monkeys by the intracerebral (i.c.) or subcutaneous (s.c.) routes. In addition viremias caused by chimeric 17D-DENV-2 and 17D-DENV-4 were compared to that of YF 17DD virus.

\section{MATERIALS AND METHODS}

\section{MONKEY SERA}

The rhesus monkeys (Macaca mulatta) were obtained from the Primatology Department of Center for Laboratory Animals (CECAL) of the Oswaldo Cruz Foundation (FIOCRUZ), Rio de Janeiro, RJ, Brazil. Blood samples were drawn from monkeys used in different tests of immunogenicity and attenuation of YF 17DD, 17D-DENV2-4 viruses. The groups were: a) intracerebral inoculation with YF 17DD virus (monkeys V79; V75; V09; V11; V43; V45; V67; V81; V85; V91; T46; U18; V60; $\mathrm{X} 13$; X15; X55; X65; X85; X89; X95), or with 17DDENV-2 (monkeys V08; V33; V39; V47; V51; V55; V61; V65; V77; V89); b) subcutaneous inoculation with YF17DD (monkeys U67; U23; U63; U69; U75, J22; J61), or with 17D-DENV-2 (monkeys I14; M14; U44) or 17D-DENV-4 (monkeys V2; R38; U60). The inoculation and blood drawing have been described (Galler et al. 2005). These studies were carried out according to the protocol approved by the Institutional Committee for Experimentation and Care of Research Animals (CEUA-FIOCRUZ: P0112/02).

\section{VIRUSES}

YF 17DD virus is the YF vaccine from Biomanguinhos, Oswaldo Cruz Foundation, Rio de Janeiro, Brazil. YF 17DD vaccine and 17D-DENV viruses were propagated in Vero cells. The supernatant was harvested when cytopathic effect (CPE) was pronounced, aliquoted and stored at $-70^{\circ} \mathrm{C}$ for later titration. Virus titer was determined by plaque assay using Vero cell monolayers in 6-well plates. The YF 17DD virus grown in Vero cells was 
serially diluted $\left(10^{-1}-10^{-7}\right)$ in normal human sera and used as control in real-time RT-PCR amplifications. The YF 17DD secondary seed lot $13 Z$ virus was used as the reference preparation in the monkey neurovirulence test. Its behavior in monkeys has been reported previously (Marchevsky et al. 2006).

\section{VIRAL RNA EXTRACTION}

Total viral RNA was isolated from $140 \mu \mathrm{l}$ of serial dilutions $\left(10^{-1}-10^{-7}\right)$ of $17 \mathrm{DD}$ vaccine virus in normal human sera and from monkey sera using QIAamp Viral RNA Mini Kit (QIAGEN Corporation, Germany), according to manufacturer's instructions.

\section{IN VITRO TRANSCRIBED RNA}

In vitro transcribed RNA was used for calibrating the real time RT-PCR. This control RNA was produced from plasmid pYFV-NS3amp (Bae et al. 2003). RTPCR on this RNA produces an amplicon of 104 base pairs (YF genome position: 4857-4961, GenBank number K02749). Serial dilutions corresponding from $10^{6}$ to $10^{0}$ copies were used to generate the calibration curve.

\section{REAL TIME RT-PCR}

Quantitative real time RT-PCR was performed in an ABI Prism 7000 Sequence Detection System (Applied Biosystems, USA). For every assay, amplifications were carried out in triplicate reactions for standard RNA and negative control, and in duplicate for the specimens. Thermal cycling conditions were designed as follows: reverse transcription at $45^{\circ} \mathrm{C}$ for $30 \mathrm{~min}$; enzyme activation at $95^{\circ} \mathrm{C}$ for $10 \mathrm{~min}$ followed by 45 cycles of $95^{\circ} \mathrm{C}$ for $15 \mathrm{sec}$ (denaturation), $60^{\circ} \mathrm{C}$ for $1 \mathrm{~min}$ (annealing/extension), with an extension of $1 \mathrm{~min}$ at $72^{\circ} \mathrm{C}$. Each PCR reaction contained $12.5 \mu \mathrm{L}$ of TaqMan ${ }^{\circledR}$ OneStep RT-PCR Master Mix Reagents (Applied Biosystem, USA), $3 \mu \mathrm{L}$ of RNA, $5 \mu \mathrm{M}$ of each primer and probe and $0.5 \mu \mathrm{L}$ of MultiScribe/RNase Inhibitor. The nucleotide sequences of the sense and anti-sense primers were 5' -AGGTCCAGTTGATCGCGGC-3' and 5'-GAGCGACAGCCCCGATTTCT-3', respectively. The sequence from the fluorogenic probe was 5 ' - TGGTCAACGTCCAGACAAAACCGAGCTTG-3' with FAM and TAMRA at the $5^{\prime}$ and $3^{\prime}$ ends, respectively. YF virus genome positions were 4857-4875, 4961-4942 and 4893-
4921, respectively, based on GenBank number K02749. The threshold cycle $(\mathrm{Ct})$ represents the PCR cycle at which the SDS software first detects a noticeable increase in reporter fluorescence above a baseline signal.

\section{Statistical Methods}

Variance analysis of regression model was calculated with software SPSS v.12.0 for Windows (SPSS, Inc 19892003). Comparative analyses of total viremia of YFV 17DD or recombinant viruses using Pearson chi-square test and Fisher exact test were performed with software StatXact v.3.1 for Windows (Cytel Software Corporation 1989-1997).

\section{RESULTS}

\section{STANDARDIZATION OF REAL TIME RT-PCR}

We have studied by real-time RT-PCR the replicative capability of live attenuated YFV 17DD virus and two recombinant viruses, 17D-DENV-2 and 4, after inoculation of rhesus monkeys.

A standard curve was established to allow estimating the number of RNA copies in monkey sera. Since all viruses studied contained the NS3 gene of YFV 17D the probes selected were directed at its sequence as established (Bae et al. 2003). The standard curve was established using in vitro transcribed RNA in decreasing concentrations $\left(10^{6}-10^{0}\right.$ copies $)$.

\section{Standard curve}

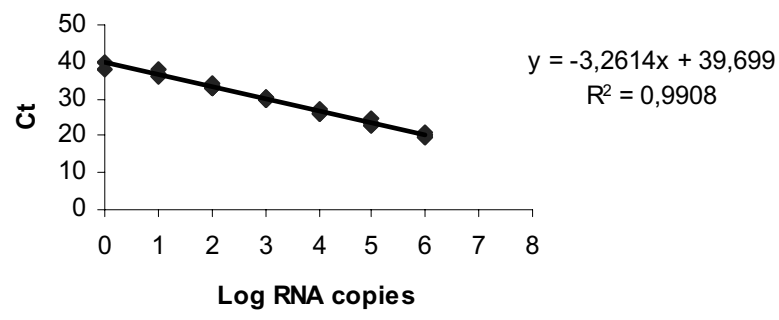

Fig. 1 - Standard curve for in vitro transcribed RNA. The standard curve was derived by linear regression including all $\mathrm{Ct}$ values shown in Table I. In the equation $(y=a x+b), a$ represents the slope $(-3.3144)$ and $b$ the intersection at the $y$ axis (39.93); $R^{2}$ indicates the correlation coeficient between the variables.

Five experiments were carried out with correlation coefficients of approximately 0.98 suggesting a high de- 
TABLE I

Correlation of $\mathrm{Ct}$ (threshold cycle) value and RNA concentration.

\begin{tabular}{c|c|c|c|c|c|c|c}
\hline \multirow{2}{*}{ Experiment } & \multicolumn{6}{|c}{ Cts in different RNA concentrations (copies / reaction) } \\
\cline { 2 - 8 } & $10^{6}$ & $10^{5}$ & $10^{4}$ & $10^{3}$ & $10^{2}$ & $10^{1}$ & $10^{0}$ \\
\hline 1 & 19.6 & 22.8 & 26.2 & 29.8 & 33.6 & 36.3 & 39.9 \\
\hline 2 & 20.1 & 23.3 & 26.2 & 30.1 & 32.9 & 36.4 & 37.9 \\
\hline 3 & 20.6 & 24.6 & 27.4 & 30.2 & 34.1 & 37.8 & - \\
\hline 4 & 20.2 & 23.3 & 26.3 & 29.9 & 32.9 & 36.8 & - \\
\hline 5 & 19.9 & 22.9 & 26.4 & 29.6 & 33.1 & - & - \\
\hline Mean & 20.1 & 23.4 & 26.5 & 29.9 & 33.3 & 36.8 & 38.9 \\
\hline SD & 0.4 & 0.7 & 0.5 & 0.2 & 0.5 & 0.7 & 1.4 \\
\hline
\end{tabular}

$\mathrm{SD}=$ standard deviation

gree of reproducibility. These experiments yielded the data in Table I, which were used to generate the plot and equation shown in Fig. 1. This equation was used for estimating the number of RNA copies in biological samples. All experiments included two points with different concentrations of in vitro transcribed RNA and RNA extracted from YFV 17DD virus. These amounts of RNA represented a lower and an intermediate limit of detection. This procedure validated the standard curve and allowed for reliable viral RNA quantification in monkey sera.

Since we expected low amounts of viral RNA in monkey sera it was important to define the sensitivity of our assay. Based on 14 experiments with the amplification of RNA from several concentrations of YFV 17DD virus (1.0 to $7.0 \log _{10} \mathrm{PFU} \mathrm{mL} \mathrm{mL}^{-1}$ ), our lowest limit of detection was 1 copy/reaction or 143 copies $\mathrm{mL}^{-1}(\mathrm{R}=0.99)$. Linearity was observed until $2.0 \log _{10}$ PFU mL $\mathrm{m}^{-1}$ (Ct 37, approximately). This is equivalent to 1,428 copies $\mathrm{mL}^{-1}$ or $3.1 \log _{10}$ copies $\mathrm{mL}^{-1}$ (Table II).

\section{Quantitation of Viral RNA In MONKEy SERA}

Samples were restricted to sera from monkeys, which had been inoculated with YFV 17DD or 17D-DENV recombinants. We have initially studied the YFV 17DD virus load after i.c. or s.c. inoculation. A second panel included a comparison between YF17DD and YF 17DDENV-2 peripheral viremia after i.c. inoculation. The third refers to the peripheral viremia of 17D-DENV-4 after s.c. inoculation.
YFV 17DD RNA quantitation in peripheral blood after i.c. and s.c inoculation

The sera of 17 monkeys inoculated with YF 17DD virus were analyzed for viremia by real-time RT-PCR. Ten were inoculated by i.c. route (T46; U18; V60; X13; X15; X55; X65; X85; X89; X95) and bled from day 1 through 6 after inoculation. Seven were inoculated by s.c. route (U67; U23; U63; U69; U75, J22; J61). The first 5 animals were bled on days 2,4 and 6 after inoculation whereas monkeys J22 and J61 were bled from day 1 through 7. Data retrieved includes the number of animals found positive, mean titer and duration of viremia.

Figure 2 shows comparatively the total number of animals found positive by plaque assay on Vero cells and real-time RT-PCR. With regard to i.c. inoculation, 10/10 animals were found positive by plaquing at day 4 but several animals were viremic between days 2 through 6 as well (Fig. 2A) with a mean peak titer of $1.72 \log _{10}$ PFU $\mathrm{mL}^{-1}$. Real-time RT-PCR detected viremia in 6 out of 10 animals restricted to days 3 to 5 p.i. (Fig. 2B) and a mean peak titer of $2.97 \log _{10}$ copies $\mathrm{mL}^{-1}$. By the s.c. route both methodologies (plaquing and real-time RT-PCR) yielded the same number of positive animals (5/7 monkeys). However, plaquing detected circulating virus on a longer time interval after inoculation ( 2 to 7 days) than did real-time RT-PCR (4 to 6 days). The highest number of positive animals was detected at the fourth day p.i. for both methodologies (Fig. 2C, D). Mean peak titers were similar to those observed after 
TABLE II

Limit of detection of YFV 17DD virus RNA by real-time RT-PCR.

\begin{tabular}{c|c|c|c|c|c}
\hline & $\mathrm{Ct}$ & $\mathrm{PFU} \mathrm{mL}^{-1}$ & PFU/reaction & Copies $\mathrm{mL}^{-1}$ & Copies/reaction \\
\hline Linearity & 37 & $\mathbf{1 0 0}\left(2 \log _{10}\right)$ & 0.7 & $\mathbf{1 , 4 2 8}\left(3.1 \log _{10}\right)$ & 10 \\
\hline Sensitivity & 40 & $\mathbf{1 0}\left(1 \log _{10}\right)$ & 0.07 & $\mathbf{1 4 3}\left(2.1 \log _{10}\right)$ & 1 \\
\hline
\end{tabular}

i.c. inoculation $\left(1.90 \log _{10} \mathrm{PFU} \mathrm{mL} \mathrm{mL}^{-1}\right.$ and $3.29 \log _{10}$ copies $\left.\mathrm{mL}^{-1}\right)$.

Total viremia is represented by the percentage of time points found positive over the total number of time points analyzed for each group of animals. Therefore, a total of 50 time points were considered for the group of monkeys inoculated i.c. with YF 17DD virus. Likewise, a total of 29 time points were analyzed for animals inoculated subcutaneously with the same virus. The data suggest that i.c. inoculation led to more significant viremia $(38 / 50$ or $76 \%)$ than s.c. inoculation $(14 / 29$ or $48 \%)$ as shown by plaquing $\left(\chi^{2} ; P=0.01\right)$. However, total viremia detected by real-time RT-PCR in sera of monkeys inoculated by either route was not significantly different $\left(9 / 50\right.$ or $18 \%$ i.c. and $8 / 29$ or $27 \%$ s.c. $\left(\chi^{2}\right.$; $P=0.32)$. The number of positive animals detected by real-time RT-PCR analysis after i.c. or s.c inoculation (6/10 or $60 \%$ and $5 / 7$ or $71.4 \%$ respectively) were not significantly different (Fisher test, $P=1.00$ ).

Based on the total number of days analyzed for viremia by plaquing and real time RT-PCR, the former was shown to be more sensitive in samples from monkeys inoculated intracerebrally with YF 17DD vaccine virus $\left(\chi^{2} ; P=0.001\right)$. However, this difference was not significant in animals, which were inoculated subcutaneously $\left(\chi^{2} ; P=0.10\right)$.

Comparison of peripheral viremia after i.c. inoculation of rhesus monkeys with YFV 17DD and 17D-DENV-2 viruses

Since neurotropism is a concern with YF 17D vaccines, a standardized neurovirulence test in monkeys was established to ensure the attenuation of any YF 17D virus. Although dengue in general is known to be non neurovirulent recent reports indicate cases of encephalitis after natural dengue infection (Solomon et al. 2000, Kalita and Misra 2006, Soares et al. 2006) Because YF 17D-
Dengue chimeric viruses contain the replicative machinery of YFV 17D virus and the envelope genes of dengue viruses their safety should be assessed in the formal neurovirulence test. One of the parameters recorded in this test is peripheral viremia.

We have quantified the presence of viral RNA in serum samples from another group of 20 monkeys, which received i.c. YFV 17DD (V79; V75; V09; V11; V43; V45; V67; V81; V85; V91) or 17D-DENV-2 (V08; V33; V39; V47; V51; V55; V61; V65; V77; V89) viruses. The total of positive animals after YFV 17DD virus inoculation was by both methods $90 \%$ (9 out of 10 animals). The magnitude and period of viremia were 0.4 to $2.83 \log _{10}$ PFU mL $\mathrm{mL}^{-1}$ and 2-6 days by plaquing (Fig. 3A) or 1.59-2.89 $\log _{10}$ copies $\mathrm{mL}^{-1}$ and $2-5$ days by real-time RT-PCR (Fig. 3B). The number of positive animals for 17D-DENV-2 virus was the same for both methodologies $(5 / 10 ; 50 \%)$ and most viremia was detected in the second day after inoculation (Fig. 3C, D). Viremia lasted only 2 days as seen by plaquing (Fig. 3C) and 3 days by real-time RT-PCR (Fig. 3D). Viremia ranged from 0.4 to $1.97 \log _{10} \mathrm{PFU} \mathrm{mL} \mathrm{mL}^{-1}$ by plaquing and from 1.34 to $3.53 \log _{10}$ copies $\mathrm{mL}^{-1}$ by real-time RT-PCR.

Table III indicates that for YFV 17DD virus the total of positive assays was higher by plaquing (31/50 or $62 \%$ ) than by real-time RT-PCR (20/50 or $40 \%)$ whereas for 17D-DENV-2 virus these numbers were close to each other $(5 / 50$ or $10 \%$ and $6 / 50$ or $12 \%$, respectively) but lower than those observed for YFV 17DD. This difference between 17DD and 17D-DENV-2 by real-time RT-PCR was statistically significant $\left(\chi^{2} ; P=0.001\right)$. By plaque assay, the mean peak titer was higher for YFV 17DD virus than 17D-DENV-2 (1.62 $\log _{10}$ and $1.07 \log _{10}$ PFU mL $\mathrm{mL}^{-1}$ ) whereas by real-time RT-PCR these titers were very close 2.41 and $2.47 \log _{10}$ copies $\mathrm{mL}^{-1}$, respectively. 
A

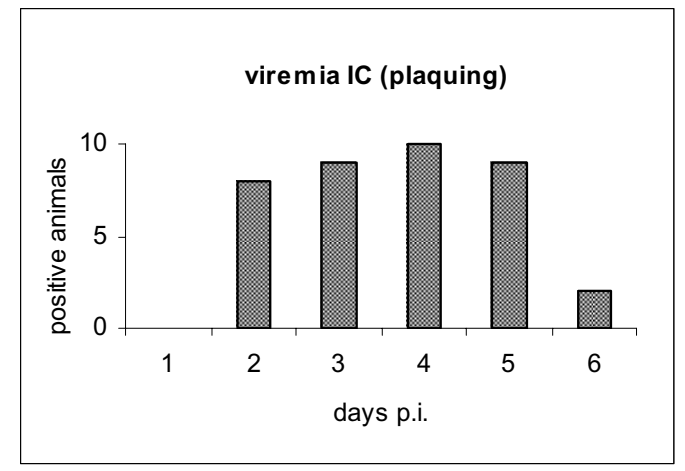

C

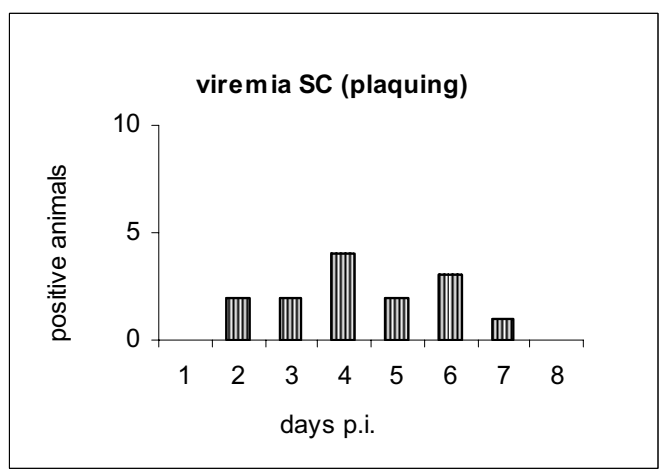

B

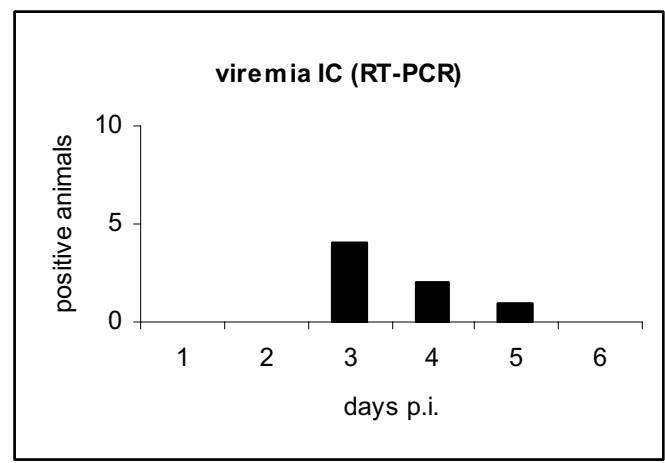

D

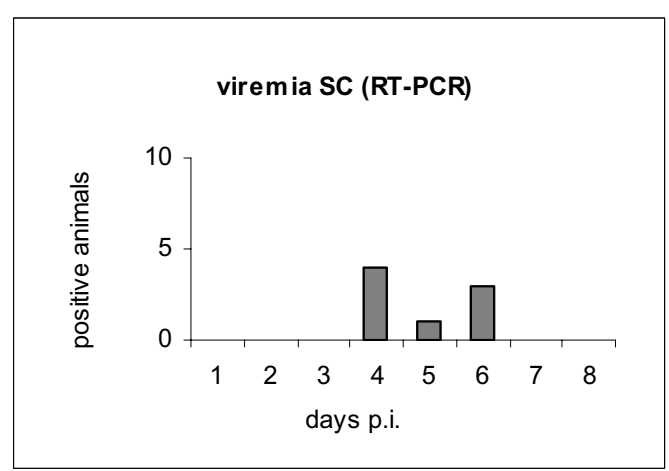

Fig. 2 - Detection of YFV 17DD virus inoculated by different routes. Intracerebral (Panels A and B); subcutaneous (Panels C and D). Positive animals / days p.i., detected by plaque assay (Panels A and C) and by real time RT-PCR (Panels B and D).

TABLE III

Viremia of YFV 17DD and 17D-DENV-2 viruses.

\begin{tabular}{c|c|c|c|c}
\hline \multirow{2}{*}{} & \multicolumn{2}{|c|}{$17 \mathrm{DD}$} & \multicolumn{2}{c}{ 17D-DENV-2 } \\
\cline { 2 - 5 } & $\begin{array}{c}\text { Real time } \\
\log _{10} \text { copies } \mathrm{mL}^{-1}\end{array}$ & $\begin{array}{c}\text { Plaquing } \\
\log _{10} \text { PFU mL }^{-1}\end{array}$ & $\begin{array}{c}\text { Real time } \\
\log _{10} \text { copies } \mathrm{mL}^{-1}\end{array}$ & $\begin{array}{c}\text { Plaquing } \\
\log _{10} \text { PFU mL }^{-1}\end{array}$ \\
\hline Total viremia & $40 \%$ & $62 \%$ & $12 \%$ & $10 \%$ \\
\hline Mean Peak Titer & 2.41 & 1.62 & 2.47 & 1.07 \\
$(\mathrm{SD})$ & $(0.35)$ & $(0.76)$ & $(0.89)$ & $(0.72)$ \\
\hline Duration & $2-5$ & $2-6$ & $2-3$ & $2-5$ \\
\hline
\end{tabular}

$\mathrm{SD}=$ standard deviation.

Comparison of peripheral viremia after s.c. inoculation of rhesus monkeys with 17D-DENV- 2 and 17D-DENV-4 viruses

A group of 6 naïve rhesus monkeys were inoculated subcutaneously with 17D-DENV- 2 or 17D-DENV-4, three animals each. Peripheral viremia was followed for 7 days by plaquing on Vero cells and real-time RTPCR. Both methodologies only detected viremia in sera of 3 monkeys that received the 17D-DENV-4 virus. All 3 animals were viremic within 2 to 6 days p.i. (Table IV). Altogether, $9 / 21$ or $43 \%$ of the total time points of 
A

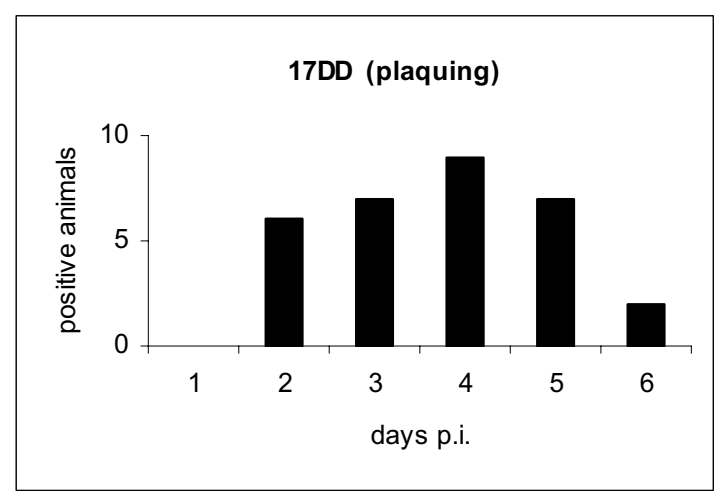

C

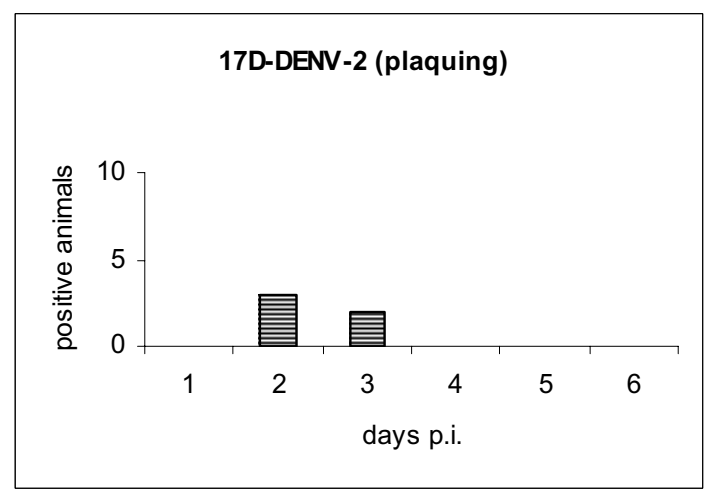

B

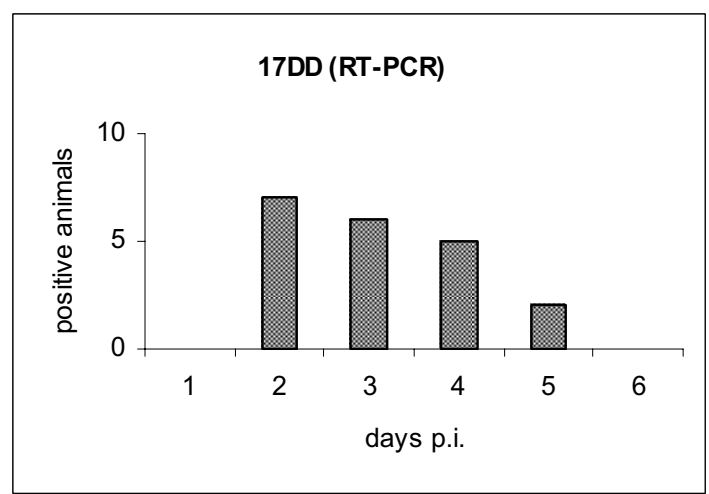

D

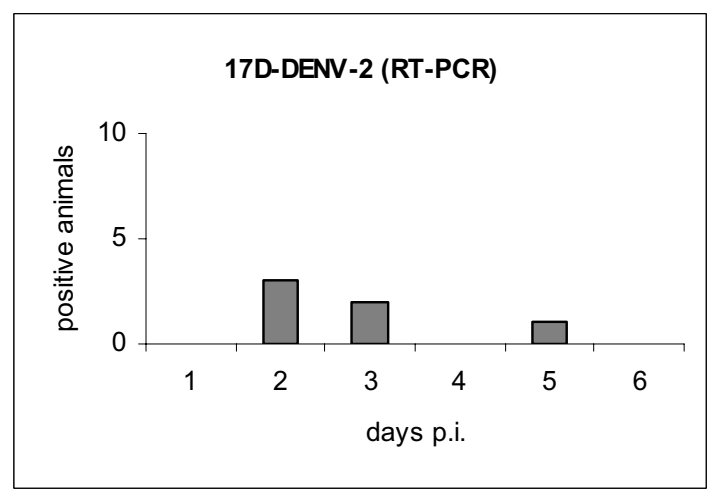

Fig. 3 - Detection of YFV 17DD and 17D-DENV-2. Parental YFV 17DD (Panels A and B) and 17D-DENV-2 (Panels $\mathrm{C}$ and D) were inoculated intracerebrally. Positive animals / days p.i. detected by plaque assay (Panels A and C) and real-time RT-PCR (Panels B and D).

viremia studied were positive by plaquing as compared to $4 / 21$ or $19 \%$ by real-time RT-PCR. This difference was not statistically significant $\left(\chi^{2} ; P=0.09\right)$. The peak of viremia was around days 2 and 3 p.i. for both methodologies with a higher mean peak titer detected by by real-time RT-PCR as compared to plaquing ( $2.48 \log _{10}$ copies $\mathrm{mL}^{-1}$ and $1.77 \log _{10} \mathrm{PFU} \mathrm{mL} \mathrm{mL}^{-1}$, respectively).

\section{DISCUSSION}

We have been interested in developing new live attenuated flavivirus vaccines based on the creation of chimeric YFV 17D viruses. A major issue relates to the attenuation of the resulting viruses as compared to the original parental YFV 17D virus, the safety of which is well known. Viral attenuation appears to be a direct measure of the viral capability to replicate (Monath 2003). The
TABLE IV

Viremia of 17D-DENV-4 recombinant virus.

\begin{tabular}{c|c|c}
\hline & $\begin{array}{c}\text { Plaquing } \\
\log _{10} \text { PFU mL }\end{array}$ & $\begin{array}{c}\text { Real time RT-PCR } \\
\log _{10} \text { copies } \mathrm{mL}^{-1}\end{array}$ \\
\hline Total viremia & $43 \%$ & $19 \%$ \\
\hline Mean Peak Titer & 1.77 & 2.48 \\
(SD) & $(0.41)$ & $(0.82)$ \\
\hline Duration & $2-6$ & $2-3$ \\
\hline
\end{tabular}

$\mathrm{SD}=$ standard deviation

replication of YF 17D virus has been shown to be limited to two logs of virus per milliliter of human or monkey serum as detected by plaque assay in tissue culture. As an alternative method to viral titration in tissue culture real-time PCR has been shown to accurately reflect the 
degree of viral replication. Here, we have employed it to comparatively estimate the infectiousness of YFV 17DD and 17D-DENV recombinant viruses after experimental inoculation of monkeys.

The detection limits of the real time RT-PCR method were at 10 copies $\mathrm{mL}^{-1}$, using as reference quantified in vitro transcribed RNA. It is noteworthy that in samples with lower concentrations of RNA $\left(<2-3 \log _{10}\right)$ reproducibility within assays and between assays resulted in higher variation coefficients, as compared to more concentrated samples. Table II shows linearity and sensitivity values established for YFV 17DD virus for realtime RT-PCR and Vero cell plaquing. Linearity was down to 1,428 copies $\mathrm{mL}^{-1}$ with the lowest sensitivity of 143 copies $\mathrm{mL}^{-1}$, similar to what has been reported by Drosten et al. (2002) for wild-type YFV. Puig et al. (2002) also have described similar values when analyzing hepatitis C-infected chimpanzee sera.

Houng et al. (2001) have suggested the limit for detection of dengue viruses in human sera is 20-50 PFU mL $\mathrm{mL}^{-1}\left(1.3-1.7 \log _{10}\right.$ PFU mL $\left.\mathrm{mL}^{-1}\right)$ with the lowest limit being $0.04 \mathrm{PFU} /$ reaction or $25 \mathrm{PFU} \mathrm{mL} \mathrm{mL}^{-1}\left(1.4 \log _{10}\right.$ PFU $\mathrm{mL}^{-1}$ ) for DENV 4 virus. Putnak et al. (2005) have evaluated the replication of live attenuated DENV 2 virus in rhesus monkey sera and were able to detect $2.1 \log _{10}$ PFU. Poersh et al. (2005) reported detection limits of $53 \mathrm{FFU}$ (focus forming units) $\mathrm{mL}^{-1}\left(1.7 \log _{10}\right.$ FFU $\mathrm{mL}^{-1}$ ) of wild-type DENV viruses in human sera using real-time RT-PCR. In our analyses the lowest detection limit for YFV 17DD virus (spiked human serum) was 10 PFU $\mathrm{mL}^{-1}$. For 17D-DENV-4 this limit was approximately $2 \log _{10}$ or 100 copies $\mathrm{mL}^{-1}$. Altogether, it is suggested that the methodology of real-time PCR used here to detect viremia in rhesus monkeys infected with YFV 17DD and 17D-DENV recombinants has comparable sensitivity to that described for related viruses.

The Asibi strain of YF virus is extremely virulent for monkeys as its inoculation by the s.c. route leads to the death of the $95 \%$ of the animals within 4-7 days, being extremely viscerotropic (Theiler 1951). Monath et al. (1981) have reported high viremia between 2 and 6 days after inoculation with titers close to $8.0 \log _{10} \mathrm{PFU} \mathrm{mL}^{-1}$. Bae et al. (2003) have studied by real-time RT-PCR the amount of virus in serum from an individual naturally infected by YF virus. A reduction of the number of RNA copies from $1.6 \times 10^{8}$ to $9.5 \times 10^{6}$ occurred within the last 3 days before the patient death. These observations indicate the high replication rate of wild-type virus in the primate host.

On the other hand YF 17D viruses, which were derived from the Asibi strain by serial passaging have lost its viscerotropism and the capability to cause high viremia, which is usually below $3.0 \log _{10} \mathrm{PFU} \mathrm{mL}-1$ (Marchevsky et al. 2003). Monkeys immunized with one human dose of YFV 17DD by the s.c. route showed a mean peak titer of $3.29 \log _{10}$ copies $\mathrm{mL}^{-1}$, within the viremia period of 4-6 days p.i. In humans vaccinated with the same virus the mean peak titer was $2.23 \log _{10}$ copies $\mathrm{mL}^{-1}$ with a period of viremia of 1-7 days p.i. (Trindade G.F. unpublished data).

Guirakhoo et al. (2000) have inoculated subcutaneously graded doses of recombinant 17D-DENV-2 virus $\left(\right.$ ChimeriVax $\left.^{\mathrm{TM}}-\mathrm{D} 2\right)$ in rhesus monkeys and noted no differences in viremia (detected by plaquing) among the groups receiving the highest and the lowest dosage (1.34 and $1.65 \log _{10}$ PFU mL $\mathrm{mL}^{-1}$, respectively). Guirakhoo et al. (2002) reported viremia caused by other chimeric 17D-DENV viruses also by plaquing and all viruses consistently showed limited replication rates with low mean peak titers (below $3.0 \log _{10}$ PFU mL $\mathrm{mL}^{-1}$ ). We constructed a similar set of recombinant 17D-DENV viruses and studied their replication after s.c. inoculation. While our 17D-DENV-2 failed to produce viremia, despite seroconversion to the respective dengue type, the viremia observed for our 17D-DENV-4 virus was of somewhat lower magnitude as compared to ChimeriVax ${ }^{\mathrm{TM}}-\mathrm{D} 4$ (1.77 versus $2.4 \log _{10}$ PFU mL $\mathrm{mL}^{-1}$ ). These apparent discrepancies may be due to differences in the nucleotide sequences among the structural genes used for the independent constructions and may reflect variable replicative properties.

The establishment of new YFV 17D seed viruses and recombinants thereof requires the analysis of viral attenuation by a standardized neurovirulence test in nonhuman primates (WHO 1998). Marchevsky et al. (2003) inoculated YFV 17DD virus by the i.c. route in 49 monkeys with the highest viremia recorded being $2.7 \log _{10}$ PFU $\mathrm{mL}^{-1}$. Here, we compared the magnitude and duration of YFV 17DD and 17D-DENV-2 viremia in monkeys inoculated by the i.c. route using viral plaquing and 
real-time RT-PCR. Although onset, duration and mean peak titers were similar for both viruses, animals were more frequently found positive at the time points studied after inoculation with 17DD than with 17D-DENV-2 virus.

We have used real-time RT-PCR to detect a segment of the YFV 17D virus genome present in all viruses studied, the commercial YFV 17DD vaccine virus, and 17D-DENV recombinants to show their limited replication. The low level of viral replication detected for these viruses by two inoculation routes provides additional evidence for their attenuation and support the use of these recombinant 17D-DENV viruses for future clinical trials towards the development of a tetravalent dengue vaccine.

\section{ACKNOWLEDGMENTS}

We thank the Instituto de Tecnologia em Imunobiológicos (Bio-Manguinhos) at Fundação Oswaldo Cruz for the continuous support to this work. We are also indebted to Dr. Antônio M. Marinho (Centro de Criação de Animais de Laboratório - CECAL/FIOCRUZ) for providing the rhesus monkeys used in all experiments. The technical assistance of José M. da Silva, Idevaldo I. Ferreira, Mauro F. da Silva and Edney do Monte is greatly acknowledged. We thank Juliano Bordignon for critical reading of the manuscript. This work was supported by Conselho Nacional de Desenvolvimento Científico e Tecnológico [CNPq (50.1526/2003-0; 472809/2003-2)], Programa de Desenvolvimento Tecnológico em Insumos para Saúde [PDTIS/FIOCRUZ (RVR10)] and the Millennium Institute for Vaccine Technology and Development.

\section{RESUMO}

Uma das principais propriedades a serem estabelecidas para o desenvolvimento de vacinas seguras e atenuadas de flavivirus, é a taxa de replicação viral. Neste trabalho, aplicamos a metodologia de amplificação pela reação em cadeia da polimerase em tempo real e titulação viral por plaqueamento para determinação da replicação do vírus 17DD (FA 17DD) e recombinantes, expressando proteínas do envelope de dengue sorotipos 2 e 4 (17D-DENV-2 e 17D-DENV-4). As amostras de soros de macacos inoculados por via intracerebral ou subcutânea com FA 17DD ou 17D-DENV foram usadas para determinar e comparar a viremia induzida por estes vírus. A quantificação da carga viral em amostras de macacos inoculados por ambas as vias com FA 17DD sugere restrita capacidade de replicação com taxa não superior a $2,0 \log _{10} \mathrm{PFU} \mathrm{mL}^{-1}$ ou 3,29 $\log _{10}$ cópias $/ \mathrm{mL}^{-1}$. Os vírus recombinantes $17 \mathrm{D}-\mathrm{DENV}$ mostraram-se tão atenuados quanto o vírus $17 \mathrm{DD}$, tanto por RT-PCR em tempo real quanto por plaqueamento, com título médio máximo de $1,97 \log _{10} \mathrm{PFU} \mathrm{mL}^{-1}$ ou $3,53 \log _{10}$ cópias $/ \mathrm{mL}^{-1}$. Estes dados servem como base comparativa para caracterização de outros vírus vivos atenuados, derivados do vírus 17D, candidatos a vacinas contra outras doenças.

Palavras-chave: febre amarela, dengue, vacina, atenuação, replicação, RT-PCR em tempo integral.

\section{REFERENCES}

Bae H-G, Nitsche A, Teichmann A, Biel SS AND NiEDRIG M. 2003. Detection of yellow fever virus: a comparison of quantitative real-time PCR and plaque assay. J Virol Methods 101: 185-191.

Bente DA And Rico-Hesse R. 2006. Models of dengue virus infection. Drug Discovery Today 3: 97-103.

Blaney JE JR, MATro JM, Murphy BR AND WhiteHEAD SS. 2005. Recombinant, live-attenuated tetravalent dengue virus vaccine formulations induce a balanced, broad, and protective neutralizing antibody response against each of the four serotypes in rhesus monkeys. J Virol 79: 5516-5528.

Calisher CH, Karabatsos N, Darymple JM, Shope RE, Porterfield JS, WestaWAy EG AND BRANDT WE. 1989. Antigenic relationships between flaviviruses as determined by cross-neutralization tests with polyclonal antisera. J Gen Virol 70: 37-43.

DURBIN AP ET AL. 2001. Attenuation and immunogenicity in humans of a live dengue virus type-4 vaccine candidate with a 30 nucleotide deletion in its 3 '-untranslated region. Am J Trop Med Hyg 65: 405-413.

Drosten C, Gottig S, Schilling S, Asper M, PanNING M, SCHMitz H AND GunTher S. 2002. Rapid detection and quantification of RNA of ebola and marburg viruses, lassa virus, crimean-congo hemorrhagic fever virus, rift valley fever virus, dengue virus, and yellow fever virus by real-time reverse transcription-PCR. J Clin Microbiol 40: 2323-2330.

Edelman R, Wasserman SS, Bodison SA, PUtnak RJ, ECKELS KH, KANESA-ThasAN N, VAUGHN DW, INNIS BL AND SUN W. 2003. Phase I trial of 16 formula- 
tions of a tetravalent live-attenuated dengue vaccine. Am J Trop Med Hyg 69 (Suppl 6): 48-60.

Galler R, Marchevsky RS, Caride E, Almeida LFC, Yamamura AMY, Jabor AV, Motta MCA, Bonaldo MC, COUTINHO ESF AND FREIRE MS. 2005. Recombinant yellow fever 17D-dengue type 2 virus: attenuation and immunogenicity for rhesus monkeys. Braz J Med Biol Res 38: 1835-1846.

GUBLER DJ. 2004. The changing epidemiology of yellow fever and dengue, 1900 to 2003: full circle? Comp Immunol Microbiol Infect Dis 27: 319-330.

Guirakhoo F, Weltzin R, Chambers TJ, Zhang ZX, Soike K, Ratterree M, Arroyo J, GeorgaKopoulus K, Catalan J and Monath TP. 2000. Recombinant chimeric yellow fever-dengue type 2 virus is immunogenic and protective in nonhuman primates. J Virol 74: 5477-5485.

GUIRAKHOO F ET AL. 2002. Viremia and immunogenicity in nonhuman primates of a tetravalent yellow fever-dengue chimeric vaccine: genetic reconstructions, dose adjustment, and antibody responses against wild-type dengue virus isolates. Virology 298: 146-159.

GUIRAKHOO F ET AL. 2006. Live attenuated chimeric yellow fever dengue type 2 (ChimeriVax ${ }^{\mathrm{TM}}$-DEN2) vaccine: phase I clinical trial for safety and immunogenicity. Human Vaccines 2: 60-67.

Houng HH, Chen RC, Vaughn DW And KanesaTHASAN N. 2001. Development of a fluorogenic RTPCR system for quantitative identification of dengue virus serotypes 1-4 using conserved and serotype-specific 3' noncoding sequences. J Virol Methods 95: 19-32.

Kalita J And MisRa UK. 2006. EEG in dengue virus infection with neurological manifestations: a clinical and CT/MRI correlation. Clin Neurophysiol 117: 2252-2256.

Kanesa-Thasan N et AL. 2001. Safety and immunogenicity of attenuated dengue virus vaccines (Aventis Pasteur) in human volunteers. Vaccine 30: 3179-3188.

LAI CJ AND MONATH TP. 2003. Chimeric flaviviruses: novel vaccines against dengue fever, tick-borne encephalitis, and japanese encephalitis. Adv Virus Res 61: 469-509.

LindenBACH BD AND RiCE CM. 2001. Flaviviridae: The viruses and their replication. In: FIELDS BN, KNIPE DM, Howley PM (Eds), Field's Virology, Lippincott Williams and Wilkins, Phildelphia, p. 991-1041.

MARChEVSKy RS, Freire MS, Coutinho ESF AND GALLER R. 2003. Neurovirulence of yellow fever 17DD vaccine virus to rhesus monkeys. Virology 316: 55-63.
Marchevsky RS, Leal ML, Homma A, Coutinho ESF, Camacho LAB, Jabor AV, Galler R AND FREIRE MS. 2006. Molecular and phenotypic analysis of a working seed lot of yellow fever virus 17DD vaccine strain produced from the secondary seed lot 102/84 with an additional passage in chicken embryos. Biologicals 34: 191-197.

MonAth TP. 2003. Yellow fever vaccine. In: PLOTKIN SA, ORENSTEIN WD (Eds), Vaccines, WB Saunders, USA, p. 1095-1176.

Monath TP, Brinker KR, Chandler FW, Kemp GE AND CROPP CB. 1981. Pathophysiologic correlations in a rhesus monkey model of yellow fever. Am J Trop Med Hyg 30: 431-443.

Poersch CO, Pavoni DP, Queiroz MH, Borba L, Goldenberg S, Santos CN and Krieger MA. 2005. Dengue virus infections: comparison of methods for diagnosing the acute disease. J Clin Virol 32: 272-277.

Puig M, Mihalik K, Yu MW, Feinstone SM and MAJOR ME. 2002. Sensitivity and reproducibility of HCV quantitation in chimpanzee sera using TaqMan realtime PCT assay. J Virol Methods 105: 253-263.

PUTNAK JR ET AL. 2005. An evaluation of dengue type-2 inactivated, recombinant subunit, and live-attenuated vaccine candidates in rhesus macaque model. Vaccine 23: $4442-4452$.

Russel PK AND NisAlaK A. 1967. Dengue virus identification by the plaque redution neutralization test. J Immunol 99: 291-296.

SABCHAREON A ET AL. 2002. Safety and immunogenicity of tetravalent live-attenuated dengue vaccines in Thai adult volunteers: role of serotype concentration, ratio, and multiple doses. Am J Trop Med Hyg 66: 264-272.

SABCHAREON A ET AL. 2004. Safety and immunogenicity of a three dose regimen of two tetravalent live-attenuated dengue vaccines in five- to twelve-year-old Thai children. Pediatr Infect Dis J 23: 99-109.

Soares CN, Faria lC, Peralta JM, de Freitas mR AND PuCCIOni-Sohler M. 2006. Dengue infection: neurological manifestations and cerebrospinal fluid (CSF) analysis. J Neurol Sci 249: 19-24.

SOlOMON T ET AL. 2000. Neurological manifestations of dengue infection. Lancet 355: 1053-1059.

SUN W ET AL. 2003. Vaccination of human volunteers with monovalent and tetravalent live-attenuated dengue vaccine candidates. Am J Trop Med Hyg 69 (Suppl. 6): 24-31. 
Sun W, Nisalak A, Gettayacamin M, Eckels KH, Putnak JR, VAughn DW, InNis BL, Thomas SJ AND ENDY TP. 2006. Protection of rhesus monkeys against dengue virus challenge after tetravalent live attenuated dengue virus vaccination. J Infect Dis 193: 16581665.

Theiler M. 1951. The virus. In: Strode GK (Ed). Yellow Fever. New York, McGraw-Hill Book Company, p. $39-138$.

Vaughn DW, Green S, Kalayanarooj S, Innis BL, Nimmannitya S, Suntayakorn S, Rothman AL, ENNIS FA AND NisalaK A. 1997. Dengue in the early febrile phase: viremia and antibody responses. J Infect Dis 176: $322-330$.
Vaughn DW, Green S, Kalayanarooj S, Innis BL, Nimmannitya S, Suntayakorn S, Rothman AL, ENNIS FA AND Nisalak A. 2000. Dengue viremia titer, antibody response pattern, and virus serotype correlate with disease severity. J Infect Dis 181: 2-9.

World Health Organization. 1998. Requirements for yellow fever vaccine. WHO Tech Rep Ser 872: 31-68. 